\title{
Heavy metal biomagnification and genotoxic damage in two trophic levels exposed to mine tailings: a network theory approach
}

\author{
Laura T. Cervantes-Ramírez¹, Mónica Ramírez-López², Patricia Mussali-Galante ${ }^{3}$ Ma. Laura Ortiz-Hernández³ \\ Enrique Sánchez-Salinas ${ }^{3}$ and Efraín Tovar-Sánchez ${ }^{4^{*}}$
}

\begin{abstract}
Background: The analysis of the negative effects of environmental metal pollution is complex and difficult to assess, because the great number of variables and levels of biological organization involved. Therefore, an integral interpretation of the structure of ecological interactions from the multifactorial toxicological vision can be achieved by the use of new analysis tools, such as the complex network theory analysis (CNT).

Results: Our results demonstrated that the trophic level has an effect on metal enrichment, being the detritivores who presented the highest bioaccumulation levels in comparison to plants, as well as higher biomagnification levels in the soil-plant-detritivores relationship. Also, Vachellia farnesiana displayed greater sensitivity to genotoxic damage than Eisenia fetida. Finally, the analysis of complex networks showed that detritivores are the key link in this dynamics, on which the interactions between heavy metals, plant and detritivores depend.

Conclusions: This study shows that there is an effect of the study site on heavy metal bioaccumulation and DNA damage induction, and that these responses are particular to each species and to each bioaccumulated metal, which in turn reveals specific sensitivity for each trophic level. Moreover, the application of CNT methodology allowed us to clarify in this particular system, the interaction types and the principal components of the trophic structure.
\end{abstract}

Keywords: Bioaccumulation, Detritivorous, Genotoxic damage, Graph, Primary producer

\section{Background}

Recently, ecosystem studies have focused on elucidating the relationship that exists between their biotic and abiotic elements, beyond an isolated interpretation of the population dynamics of the different species that compose them [1]. A new frontier in the trophic interaction studies is the analysis of complex ecological networks, which combine qualitative and quantitative characters, in order to identify, from a holistic approach, those ecological properties that are not evident through direct observation or not even through the sum of its parts $[1,2]$.
Complex Network Theory (CNT) refers to a set of interactions that has one or all of the properties of: (a) self-organization, (b) self-similarity, (c) attractor, (d) small world and (e) free scale, present in a group of variables directly and indirectly related [3]. The Complex Theory refers to systems composed by many parts, each having its own internal structure, and these in turn are in charge of carrying out a specific function that influences the structure of the interactions at different network levels [4]. Therefore, what modifies a part of the network can affect, in a highly non-linear way, the whole system [5].

\footnotetext{
* Correspondence: efrain_tovar@uaem.mx

${ }^{4}$ Laboratorio de Marcadores Moleculares, CIByC, UAEM, Universidad 1001, C.P. 62209 Chamilpa, Morelos, Mexico

Full list of author information is available at the end of the article
}

(c) The Author(s). 2018 Open Access This article is distributed under the terms of the Creative Commons Attribution 4.0 International License (http://creativecommons.org/licenses/by/4.0/), which permits unrestricted use, distribution, and reproduction in any medium, provided you give appropriate credit to the original author(s) and the source, provide a link to the Creative Commons license, and indicate if changes were made. The Creative Commons Public Domain Dedication waiver (http://creativecommons.org/publicdomain/zero/1.0/) applies to the data made available in this article, unless otherwise stated. 
Application of the CNT has been increasing since the twentieth century, with extensive studies in social sciences [6], computer science [7], transport [8], and biological sciences [9]. In particular, the CNT has been increasingly accepted in ecological studies over the last 17 years, and its development is fast and consistent [10], being a robust tool for ecosystem stability analysis, with possible applications in biodiversity and conservation [11], and as an indicator of the ecosystem health [1]. This high diversity of applications shows its universality and makes possible the comparison between structural differences between networks, even between different knowledge areas and different variables that because of their different origin, they cannot be analyzed by conventional methods, a fact that is well recognized as one of the advantages of this methodology [5].

In environments impacted by mining activity, the analysis of the interactions between the exposed organisms and the ecosystem health, has become an issue of international relevance [12]. In particular, metals derived from mine wastes, which are called tailings, can be accumulated in living organisms, either by consumption, inhalation, or cutaneous absorption, which induces their transfer along the trophic chain involved, endangering the dynamics of the ecosystem, including humans $[13,14]$.

To understand the ecological impact caused by heavy metal exposure, we should analyze not only the metal mixture involved and their concentrations in the abiotic and biotic components, but also their relative mobility and their bioaccumulation potential within and among different trophic levels [15-17].

In ecotoxicological studies, the risk analysis from a multispecies approach is essential. The difference between the sensitivity of populations exposed to the same pollutant is a tool that allows the application of strategies for environmental management [18]. Research on heavy metal transfer through the food chain, as well as its genotoxic effects at these levels, is important and urgently required. However, because of the complex interactions within metal mixtures, the great number of exposed species and the biological responses, studies to date haven't been performed from an integrative approach [19]. Within terrestrial ecosystems, primary producers and detritivores are key links of food webs, for being in the base of the chain, and for its role as decomposers of organic matter, respectively [20]. In particular, Vachelia farnesiana and Eisenia fetida are good study system because: (a) they are in close contact with the pollutants, (b) they have the ability to bioacumulate heavy metals, (c) they play a key role in the ecosystem in function of their biomass and density, (d) V. farnesiana is considered as a heavy metal hiperaccumulator species, (e) E. faetida is considered as a bioindicator species. Hence, the aims of the present study are A) to analyze heavy metal transfer along the trophic chain [soil, primary producers ( $V$. farnesiana (L.) Wight \& Arn 1834), and detritivores (E. fetida Savigny 1826)] in Santa Rosa, Taxco de Alarcón, Guerrero State, Mexico, B) to evaluate in both species the influence of the heavy metal bioaccumulation on genetic integrity, and C) to characterize from the CNT perspective, the structure of the relationship between heavy metal bioaccumulation, genetic damage and the analyzed species (primary producers and detritivores) in Santa Rosa mine tailings.

\section{Methods}

\section{Study area}

The mine tailing "El Fraile" is located at $12 \mathrm{~km}$ southwest of Taxco city, Guerrero State, Mexico, between Santa Rosa and El Fraile towns, where the mining activity was suspended in 1970 [21]. This mine was considered as the most productive for the Taxco mining district, particularly for the exploitation of the mineral like galena, sphalerite and pyrite [21]. As a consequence of mining activities, two tailings were deposited in Santa Rosa, which were selected for this study, located at $18^{\circ}$ $30^{\prime} 00^{\prime \prime} \mathrm{N}$ and $99^{\circ} 40^{\prime} 00^{\prime \prime} \mathrm{W}$ (Fig. 1). Tailing 1 is $470 \mathrm{~m}$ long, $170 \mathrm{~m}$ wide and $60 \mathrm{~m}$ height [22]. The second one is $470 \mathrm{~m}$ long, $170 \mathrm{~m}$ wide, with an average thickness of $30 \mathrm{~m}$ [22], representing a total of $7,191,000 \mathrm{~m}^{3}$ of mining waste. Bioavailability of heavy metals reported for both tailings show the following concentration pattern: $\mathrm{Zn}>\mathrm{Pb}>\mathrm{Mn}>\mathrm{V}>\mathrm{Cu}>\mathrm{As}>\mathrm{Ni}>\mathrm{Cd}$ [23-25]. Both study sites have a pH between 2.44 and 5.28 in $79 \%$ of their structure, and a variable granulometry, equivalent to fine and thick sand and sludges [23, 24]. As control sites, two populations of $V$. farnesiana both located at $8 \mathrm{~km}$ from the exposed site were selected.

\section{Animal and plant sampling}

Lines of $100 \mathrm{~m}$ were traced in every study site (two lines in each exposed site and two lines in each control site). For plant sampling, the closest individual sampling technique was selected. An individual of $V$. farnesiana was selected every $10 \mathrm{~m}$ (between 2.5 and $3 \mathrm{~m}$ height) $(n=80)$. From each plant, two leaf samples were collected from leaves with no apparent damage. One of the samples was used for nuclei isolation, which were processed for the alkaline gel electrophoresis or comet assay. The other one was dried at room temperature, ground and stored in sterile plastic containers for heavy metal analysis by inductively coupled plasma mass spectrophotometry. 


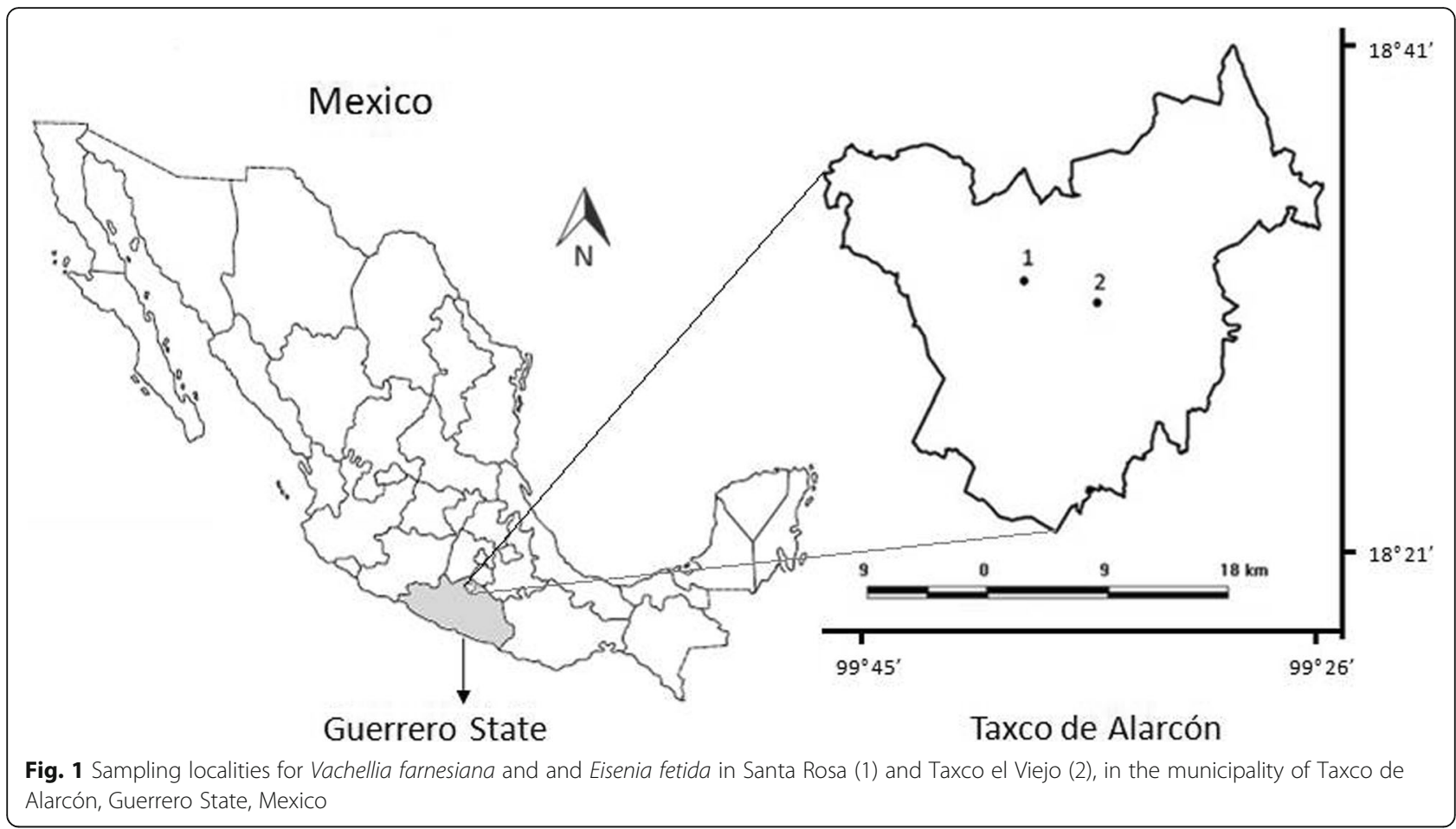

For E. fetida sampling, lines of $100 \mathrm{~m}$ were traced as described before. Every $10 \mathrm{~m}$, substrate was dug; and five to 10 worms with well-defined clitelum were captured. The sampled individuals were placed in dark containers $(25 \times 25 \times 15 \mathrm{~cm})$ with moistened paper towels, and covered with foil. The selected worms were purged for a period of 24 to $48 \mathrm{~h}$ in dark boxes with moistened paper towels, to eliminate both excess of mine tailing and soil from their digestive tract. Later, from each box, three individuals (30 per transect) were randomly selected. In general, these worms kept a reddish coloration, were reluctant to contact and showed an individual weight within the range of 300 to $600 \mathrm{mg}$. A total of 80 individuals (20 per line) were sampled for coelomocytes, for the alkaline comet assay analysis $(\mathrm{pH} 13)$. On the other hand, 20 individuals per site $(n=80)$ were dried at constant temperature $\left(60{ }^{\circ} \mathrm{C}\right)$, thereafter, were ground and stored in sterile plastic containers for heavy metal analysis by inductively coupled plasma mass spectrophotometry.

\section{Metal concentration analysis in Vachellia farnesiana and in Eisenia fetida}

A total of 48 samples (24 for V. farnesiana and 24 for $E$. fetida) were evaluated for metal concentration analysis (As, Cd, Cu, Mn, Ni, Pb, V, and Zn). $250 \mathrm{mg}$ of $V$. farnesiana leaf structure and $250 \mathrm{mg}$ of $E$. fetida tissue were pulverized in previously washed
$\mathrm{HNO}_{3}$ containers. Samples were subjected to acid digestion using a Microwave Accelerated Reaction System $\left(\mathrm{CEM}^{\circ}\right.$ MARS-5) with a 4:1 mixture of $\mathrm{HNO}_{3}$ $65 \%$ and $\mathrm{HCl} \mathrm{37 \%} \mathrm{(JT} \mathrm{Baker)} \mathrm{in} \mathrm{closed} \mathrm{Teflon} \mathrm{bombs.}$ The samples were solubilized and dissolved in distilled water and filtered; this solution was diluted to a final volume of $50 \mathrm{~mL}$ until analysis. A sample without tissue was processed simultaneously which was used as a control. Thereafter, metals were analyzed by inductively coupled plasma mass spectrometry (MS Series ICP-MS Systems, Bruker, MA USA). The instrument was calibrated with standard solutions containing known concentrations of each element. Standard Reference Material of the National Institute of Technology and internal reference materials were used for precision, quality assurance and control for selected metal measurements.

\section{Alkaline gel electrophoresis or comet assay}

The plant samples were washed, gently dried and immersed in beakers with $20 \mathrm{~mL}$ of cold phosphate buffered saline (PBS 1X) for the nuclei isolation. The purged worms were placed in a glass petri dish with $3 \mathrm{~mL}$ of cold extrusion solution (1X PBS). Subsequently, $50 \mu \mathrm{L}$ of the cell suspension was taken in both cases, and incorporated into an eppendorf tube with $50 \mu \mathrm{L}$ of low melting point agarose ( $1 \%$ LMPA). After the suspension of plant or animal nuclei, $80 \mu \mathrm{L}$ of the solution was taken 
and placed on a slide with a preformed monolayer of normal fusion agarose (NMA 1.0\% Gibco). Thereafter, covered with a coverslip and held on ice for $5 \mathrm{~min}$. The coverslip was removed and a final layer of LMPA $(0.5 \%)$ was placed at $4{ }^{\circ} \mathrm{C}$ for $5 \mathrm{~min}$. From each sample two slides were prepared [26].

The gels were placed in a cold lysis solution $(2.5 \mathrm{M}$ $\mathrm{NaCl}, 100 \mathrm{mM}$ EDTA, $10 \mathrm{mM}$ Trisma-base $\mathrm{pH}$ 10) at $100 \mathrm{~mL}$ with $1 \%$ Triton-X and 10\% Dimethyl Sulfoxide (DMSO) $10 \%$ in Kopling vessels at $4{ }^{\circ} \mathrm{C}$ for $1 \mathrm{~h}$. Subsequently, the gels were placed in an electrophoresis chamber and covered with cold alkaline buffer $[\mathrm{NaOH}(300 \mathrm{mM})+1 \mathrm{mM}$ EDTA $]$ at $\mathrm{pH} 13.0$ for $20 \mathrm{~min}$ for the DNA unwinding process. The electrophoresis was performed at $300 \mathrm{~mA}$ and $25 \mathrm{~V}$ for $20 \mathrm{~min}$ for plant samples and $5 \mathrm{~min}$ for animal samples, under dark conditions.

Finally, the gels were washed three times with neutralizing buffer Tris $(0.4 \mathrm{M} \mathrm{pH}=7.5)$ for $5 \mathrm{~min}$ [26] and fixed with cold absolute ethanol for $10 \mathrm{~min}$ for later reading using Comet IV software integrated in the fluorescence microscope with excitation filters from 515 to $560 \mathrm{~nm}$, and a $590 \mathrm{~nm}$ barrier filter.

\section{Data analysis}

In order to establish the bioaccumulation pattern of the trophic level mine tailings (soil) - plant and between the mine tailing - worm, as well as the biomagnification pattern in the trophic level plant-worm, the heavy metal enrichment values were determined. This was calculated as the quotient of each metal concentration detected at the trophic level evaluated (plant, earthworm), on the previous level (mine tailing, primary producer).

To analyze the effect of metal bioaccumulation on DNA damage in the exposed and control groups (tailing 1 vs. tailing 2 vs. control 1 vs. control 2) a two-way ANOVA analysis was performed [27] using the comet tail length value of 100 consecutive nuclei of each individual (50 nuclei per individual). Subsequently a Tukey post-hoc test of multiple comparisons was made to determine statistically significant differences between groups.

The specific sensitivity for each taxa, represented by an increase on genetic damage, was calculated, through the resulting quotient from the division of genotoxic damage (tail length) observed at the exposed sites, on the genotoxic damage values detected in control individuals. This was performed independently for each studied species [18]. Thereafter, the effect of the metal mixture on genetic damage levels (tail lenght) in $V$. farnesiana and E. fetida was estimated using a multiple regression approach. The software used for statistical analysis was STATISTICA 8.0.
Finally, to evaluate the relationship between distinct trophic levels, the CNT was applied [28]. A matrix interaction was constructed in order to identify the established links between: (a) the exposed sites (tailing 1 and 2), (b) the studied species ( $V$. farnesiana and E. fetida), (c) the metal concentrations in tailings, (d) in plant and (e) animal tissues, as well as the (f) genotoxic damage in both species. The sites and the individuals of both species were considered as structural data sets in the network and as composition data the variables: metal concentration and genotoxic damage. Each variable in the network analysis was considered equal and a unimodal approach was established. To this end, and for computational efficiency, the scoring metrics used in this study [metal concentration $(\mathrm{mg} / \mathrm{kg}$ ) and genotoxicity $(\mu \mathrm{m})]$ require that the data be discretized into the categories established as follows: $\mathrm{Al}$, low $[<1000]$, medium [1000-5000] and high [ $>5000]$; As, low $[<50]$, medium [50-100] and high [ $>100]$; $\mathrm{Ba}$, low $[<20]$, medium [20-30] and high [ $>30]$; Ca, low $[<1400]$, medium [1400-1500] and high [>1500]; Cd, low $[<100]$, medium [100-200] and high [ $>200]$; Co, low $[<3]$, medium [3-9] and high [>9]; $\mathrm{Cu}$, low $[<10]$, medium [10-40] and high [ 40]; Fe, low $[<500]$, medium [5005000] and high [ $>5000] ; \mathrm{Mg}$, low $[<1500]$, medium [1000-2000] and high [> 2000]; Mn, low $[<50]$, medium [50-100] and high $[>100]$; Mo, low $[<1]$, medium [1-3] and high $[>3]$; Ni, low $[<30]$, medium [30-60] and high $[>60] ; \mathrm{Pb}$, low $[<100]$, medium $[100-300 \mathrm{~kg}]$ and high $[>300] ; \mathrm{V}$, low $[<5]$, medium [5-15] and high $[>15] ; \mathrm{Zn}$, low $[<100]$, medium [100-500] and high [> 500]; and for DNA damage tail length $[<10]$, medium $[10-40]$ and high [41-95].

Subsequently, the fitness subgrouping of nodes was established to two, three and four factions to determine the highest propensity to generate network links [29]. Thereafter, and in order to facilitate its visualization, the network was simplified according to the main connections established (48 nodes for graphic 1 and 52 nodes for graphic 2). Betweenness was calculated for the main nodes determination, acting as the bridge between other nodes along the network [30]. Closeness measure was used to determine the accessibility of a node to the rest of the network [31], and the eigenvector centrality value calculated for the identification of the node with greater influence [32]. The networks were performed using the NetDraw 2.084 program [33], under free scale model with infinite number of interactions for analysis, visualization, and contrast of the results [34]. Moreover, in order to validate the characteristics of the obtained networks we made a degree distribution graph for each one [5]. For detailed information about the CNT methodology, see Newman [5]. 


\section{Results}

Bioaccumulation and biomagnification of heavy metals Seven heavy metals and a metalloid previously recorded in Taxco mine tailings were detected in tissue leaf samples of $V$. farnesiana and in the worm, $E$. fetida. In $V$. farnesiana, the accumulation pattern was: zinc $(\mathrm{Zn})>$ vanadium $(\mathrm{V})>$ copper $(\mathrm{Cu})>$ nickel $(\mathrm{Ni})>$ lead $(\mathrm{Pb})>$ cadmium $(\mathrm{Cd})>\operatorname{arsenic}(\mathrm{As})$. In contrast, the worm bioaccumulation pattern was: $\mathrm{Zn}>$ $\mathrm{Pb}>\mathrm{Cd}>\mathrm{Mn}>\mathrm{As}>\mathrm{Cu}>\mathrm{Ni}>\mathrm{V}$ (Table 1).

No enrichment values higher than 1.0 were found in the trophic level mine tailing-plant, but for the mine tailing -worm relationship, we found enrichment values higher than 1.0. As $(1.481 \pm 1.28)$, Cd $(11.489 \pm 6.98)$ and $\mathrm{Ni}(1.285 \pm 1.09)$, being $\mathrm{Cd}$ the element that showed highest bioaccumulation values in E. fetida (Table 1). Regarding the plant-worm trophic level, the biomagnification of six metallic elements was evidenced: As (803.712 \pm 694.47$), \mathrm{Cu}(10.556 \pm 3.17), \mathrm{Cd}(1210.117 \pm$ 735.31), Ni (8.975 \pm 7.64$), \mathrm{Pb}(1276.846 \pm 1167.91)$ and Zn: $20.045 \pm 6.92$ ) (Table 1).

\section{Genotoxic damage}

Results of DNA damage analysis of $V$. farnesiana foliar tissue and E. fetida celomocytes, showed a significant effect of the site (control 1, control 2, tailing 1 and tailing 2) on the induction of single strand breaks independently of the evaluated species $\left(F_{3,76}=769.35, P\right.$ $<0.001$ and $F_{3,76}=762.74, P<0.001$, respectively). The organisms established in mine tailings (tailing 1 and tailing 2) presented the highest values of genotoxic damage in relation to the organisms established in the control sites, regardless of the species (Fig. 2). On the other hand, it was observed that $V$. farnesiana populations established in the mine tailings presented 13.16 times more genotoxic damage than the control populations (14.28 with respect to tailing 1 and 12.04 with tailing 2). In contrast, exposed populations of $E$. fetida showed 5.03 times more damage than the control populations (5.47 for tailing 1 and 4.60 for tailing 2 ). In both cases, it was observed that the highest genotoxicity values occur in the individuals established in tailing 1 with respect to the control sites, regardless of the species evaluated. Finally, we observed that for $V$. farnesiana the genotoxicity levels were statistically and positively related with $\mathrm{Pb}$ concentrations $\left(F_{1,13}=6.784, P<0.05\right)$, but not with $E$. fetida where a statistically and positive relationship was observed for Co $\left(F_{1,13}=9.678, P<0.01\right)$, Ni $\left(F_{1,13}\right.$ $=4.973, P<0.05)$ and $\mathrm{Zn}\left(F_{1,13}=24.774, P<0.001\right)$.

\section{Network analysis}

The relationship between heavy metal concentration, species type and study site showed that the nodes subgrouping with the greater fitness is given to two factions (394.000), in which the differentiation between subgroups is delimited by the species ( $V$. farnesiana and E. fetida) (Fig. 3). Also, the highest betweenness and eigenvector centrality values were given by E. fetida from tailing 1 (479.000 and 0.444 respectively), followed by the same species in tailing 2 (433.000 and 0.421 respectively), which identifies $E$. fetida as the main link between the network nodes and the most influential node (Appendix 1).

Likewise, the lowest measures of closeness were presented in E. fetida (123.000 in individuals from tailing 1 and 125.000 in individuals from tailing 2) (Appendix 1).While it is true that a bidirectional relationship between the nodes of worms and the nodes of the study plant for each site is observed, the high values of centrality of detritivorous showed greater

Table 1 Average values ( \pm SD) of soluble heavy metal concentrations detected in mine tailing, Vachellia farnesiana (foliar tissue), and Eisenia fetida (earthworm), and their enrichment values in the throphic levels (tailing-plant, tailing-earthworm, and plant-earthworm) in Santa Rosa, Guerrero State, Mexico

\begin{tabular}{|c|c|c|c|c|c|c|}
\hline \multirow[t]{2}{*}{ Metal } & \multicolumn{3}{|c|}{ Concentration (mg / kg) } & \multicolumn{3}{|l|}{ Enrichment } \\
\hline & Tailing $^{a}$ & Plant & Earthworm & Tailing-Plant & Tailing-Earthworm & Plant-Earthworm \\
\hline As & $38.001 \pm 16.486$ & $0.072 \pm 0.009$ & $56.260 \pm 22.213$ & $0.002 \pm 0.002$ & $1.481 \pm 0.732$ & $803.713 \pm 402.075$ \\
\hline $\mathrm{Cu}$ & $108.549 \pm 32.156$ & $2.856 \pm 0.193$ & $30.189 \pm 10.334$ & $0.027 \pm 0.008$ & $0.278 \pm 0.130$ & $10.556 \pm 3.451$ \\
\hline $\mathrm{Cd}$ & $9.478 \pm 2.021$ & $0.087 \pm 0.027$ & $108.911 \pm 63.127$ & $0.008 \pm 0.002$ & $11.488 \pm 3.902$ & $1210.118 \pm 523.656$ \\
\hline $\mathrm{Mn}$ & $409.005 \pm 187.101$ & $99.002 \pm 25.001$ & $59.070 \pm 11.567$ & $0.237 \pm 0.076$ & $0.144 \pm 0.056$ & $0.597 \pm 0.173$ \\
\hline $\mathrm{Ni}$ & $16.201 \pm 4.002$ & $2.323 \pm 1.081$ & $20.821 \pm 7.862$ & $0.141 \pm 0.006$ & $1.285 \pm 0.245$ & $8.975 \pm 2.645$ \\
\hline $\mathrm{Pb}$ & $1108.807 \pm 341.011$ & $0.144 \pm 0.120$ & $178.758 \pm 29.971$ & $10^{-4} \pm 10^{-5}$ & $0.161 \pm 0.026$ & $1276.846 \pm 736.820$ \\
\hline V & $157.786 \pm 47.231$ & $4.844 \pm 2.070$ & $2.824 \pm 0.711$ & $0.031 \pm 0.005$ & $0.018 \pm 0.007$ & $0.582 \pm 0.286$ \\
\hline $\mathrm{Zn}$ & $1426.193 \pm 112.244$ & $20.133 \pm 17.201$ & $403.495 \pm 98.567$ & $0.009 \pm 0.001$ & $0.283 \pm 0.178$ & $20.044 \pm 2.938$ \\
\hline
\end{tabular}

${ }^{a}$ Average obtained from Talavera et al. [25], Galarza [23], Ruiz \& Armienta [24] 


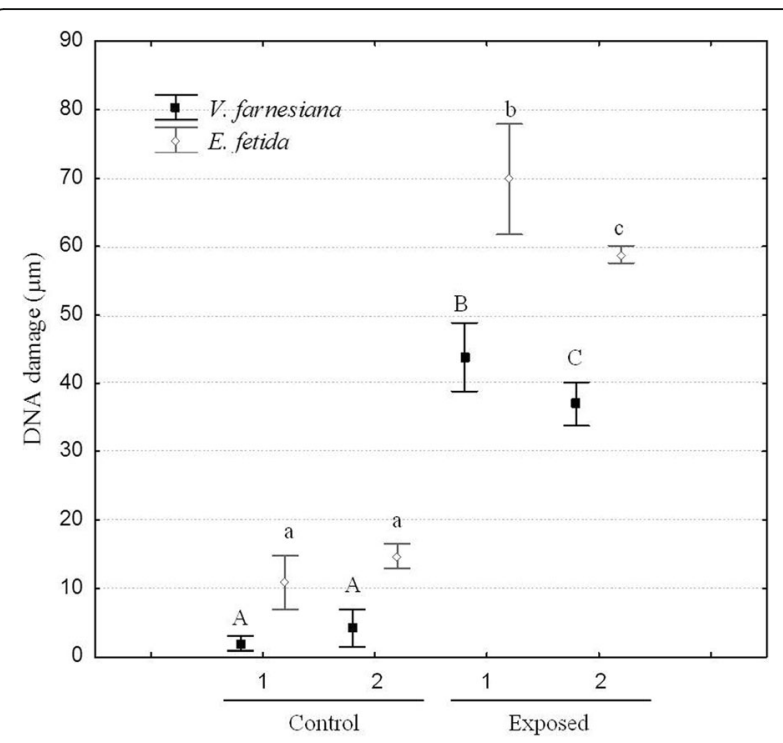

Fig. 2 Average value ( $\pm \mathrm{EE}$ ) of tail length $(\mu \mathrm{m})$ of Vachellia farnesiana leaf cells, and Eisenia fetida celomocytes collected in the Santa Rosa mine tailing (exposed 1 and exposed 2), and control populations (control 1 and control 2). Capital and lowercase letters represent significant differences between sites for Vachellia farnesiana and Eisenia fetida respectively (Tukey test, $P<0.05$ ) influence on the established links in the network, including the primary producer (Fig. 3).

Additionally, in the degree distribution analysis for heavy metal bioaccumulation in $V$. farnesiana and in E. fetida, a structure like a free scale was detected, where the nodes (48) establish 166 interactions, being the vertex "E. fetida tailing 1" and "E. fetida tailing 2" which presented the highest degree of connectivity in the network (27 and 25 respectively) concentrating the $31.33 \%$ of the links which confirms its central role (Fig. 4).

The relationship between heavy metal concentration, DNA damage and species per site showed a similar pattern in the network (Fig. 3). In the nodes subgrouping, the analysis of two factions showed the highest fitness (450.000), establishing the differentiation of two groups, one for each species ( $V$. farnesiana and $E$. fetida) (Fig. 5). The highest values of betweenness and eigenvector centrality were given by worms from mining tailing 1 (515.583 and 0.444 respectively), followed by the same species from the tailing 2 (483.083 and 0.413 respectively) (Appendix 2).

Finally, the lowest closeness measures were presented in E. fetida (132 individuals for tailing 1 and 133 in individuals from tailing 2) (Appendix 2).

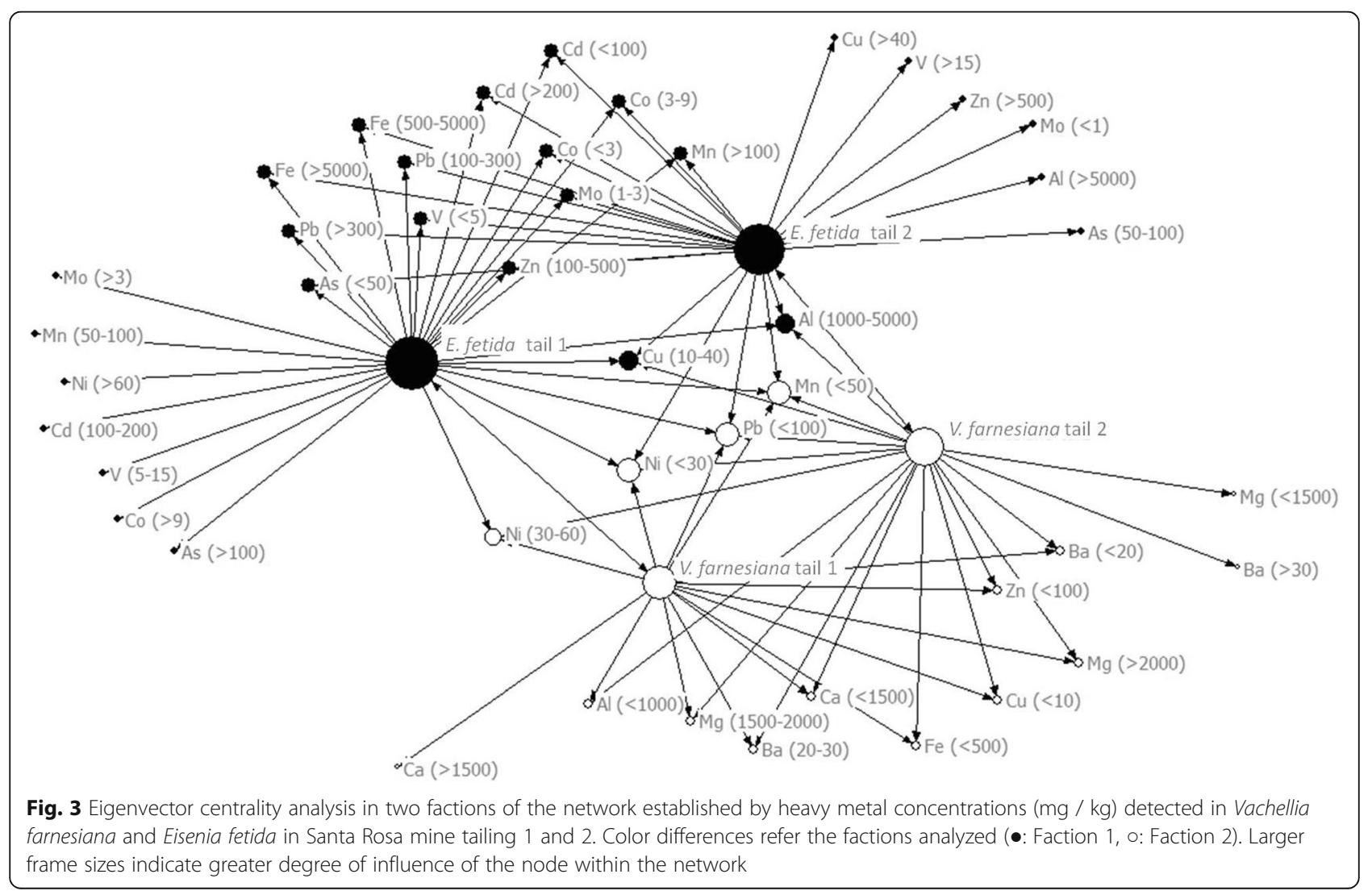




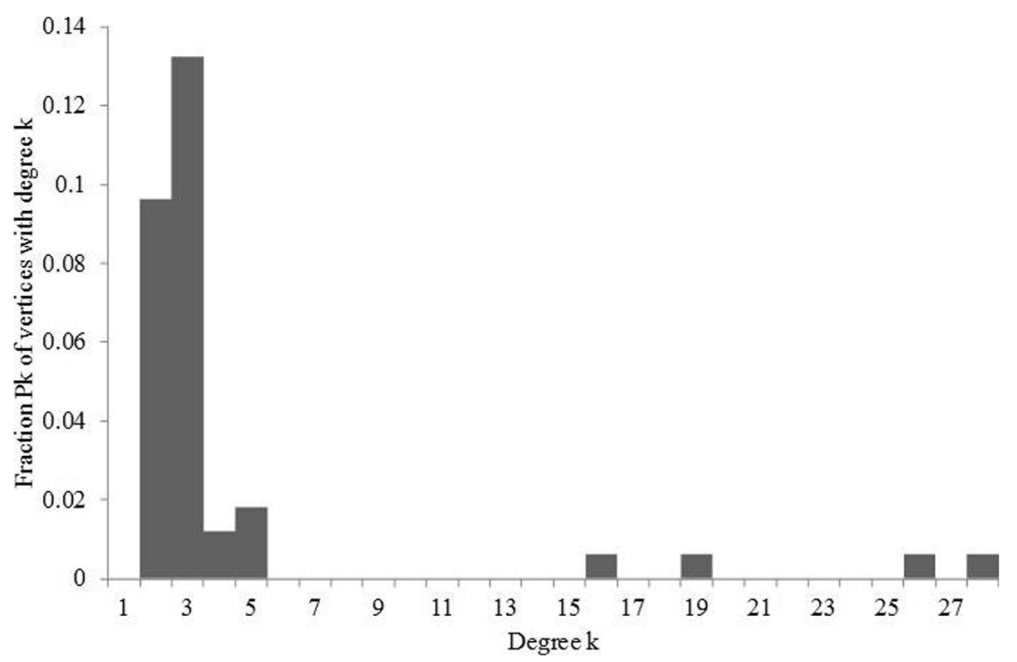

Fig. 4 Degree distribution graph of the network established by heavy metals concentrations ( $\mathrm{mg} / \mathrm{kg}$ ) detected in Vaquellia farnesiana and Eisenia fetida in Santa Rosa mine tailings 1 and 2

Network analyses (Fig. 4) showed that both metal concentration and genotoxic damage are linked to the nodes of each species, being the detritivorous the most influenced by the major eigenvector centrality (Fig. 5).

In the degree distribution analysis for the relationship between heavy metal concentrations and genotoxic damage detected in $V$. farnesiana and in E. fetida a structure like a free scale was detected, where the nodes (52) established 178 interactions, being the vertex "E. fetida tailing 1" and "E. fetida tailing 2" which represent the highest degree of connectivity in the network (28 and 26 respectively), concentrating the $30.34 \%$ of the links which confirms again its central role (Fig. 6).

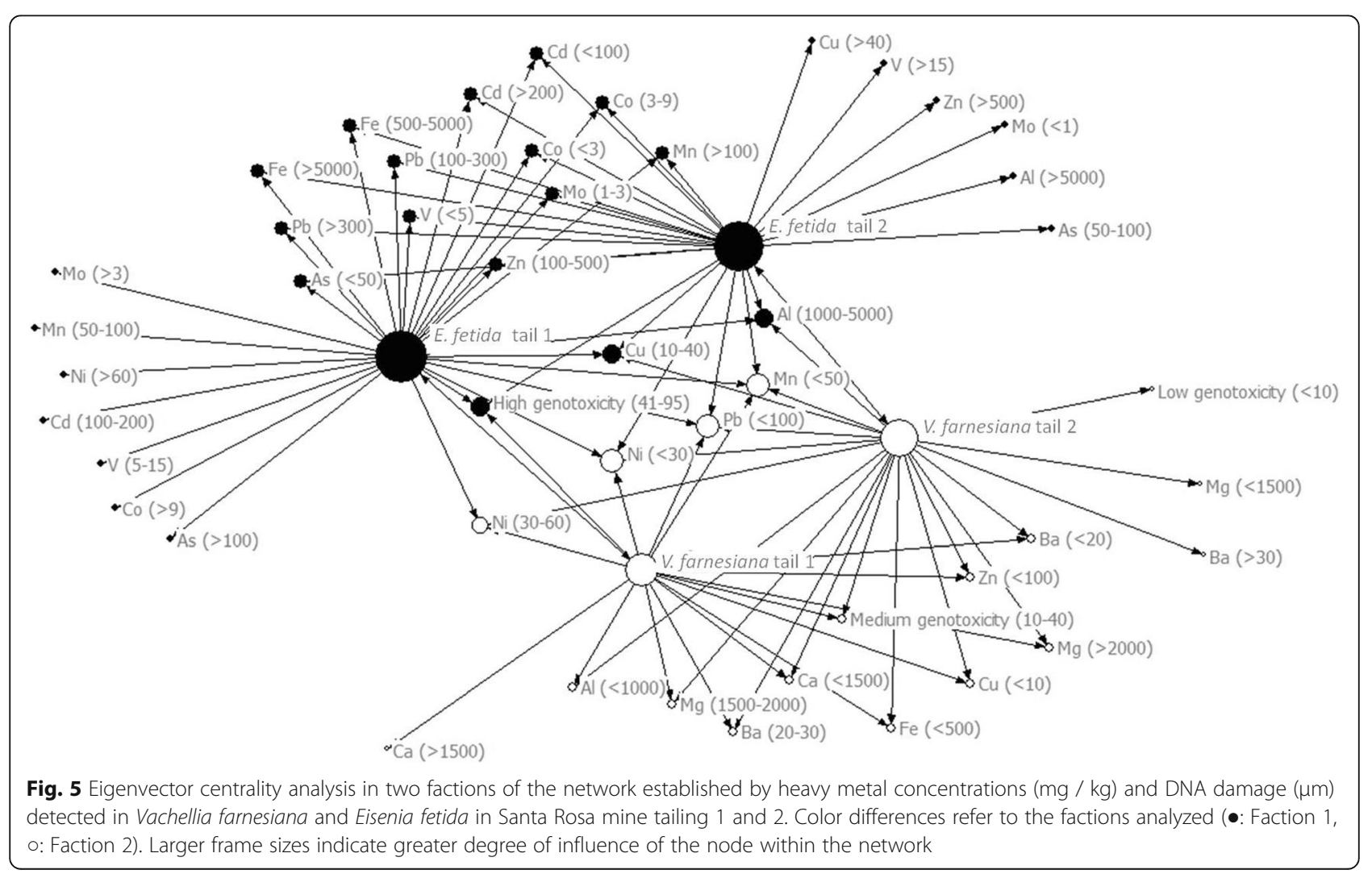




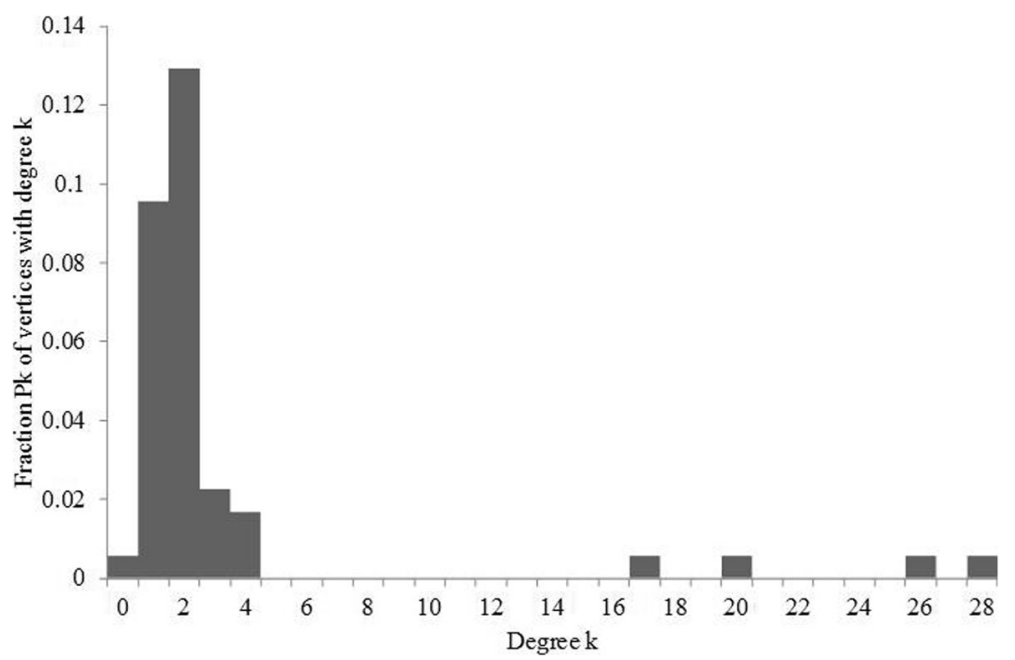

Fig. 6 Degree distribution graph of the network established by heavy metals concentrations ( $\mathrm{mg} / \mathrm{kg}$ ) and DNA damage ( $\mu \mathrm{m})$ detected in Vaquellia farnesiana and Eisenia fetida in Santa Rosa mine tailings 1 and 2

\section{Discussion}

\section{Bioaccumulation and biomagnification of heavy metals}

The concentrations of bioavailable heavy metals reported for the "El Fraile" mine site in Santa Rosa recorded the following pattern: $\mathrm{Zn}>\mathrm{Pb}>\mathrm{Mn}>\mathrm{V}>$ $\mathrm{Cu}>\mathrm{As}>\mathrm{Ni}>\mathrm{Cd}[23-25]$. This pattern is different to the observed bioaccumulation pattern in $V$. farnesiana foliar tissue. This may be explained by the fact that heavy metal transfer from soils to plants is carried out differently depending on edaphic characteristics and plant species $[35,36]$. For example, it has been documented in plant species that the type of element and the accumulated amount depends primarily on the ability of the radical cells to concentrate nutrients, and exclude the toxic elements [37]. In addition, the detected concentration in foliar tissue will depend on the transportation of these elements from the root [38].

The highest concentrations of essential heavy metals detected in this study $(\mathrm{Cu}, \mathrm{Co}, \mathrm{Fe}, \mathrm{Mn}$ and $\mathrm{Zn})$ are due to the existence of specific protein transporters that facilitate their mobility trough the foliar tissue, in which process participates mainly the ZIP family of metal transporter proteins (ZRT / IRT proteins) [39]. On the contrary, $\mathrm{Pb}$ and As low concentrations detected can be attributed to the fact they are usually retained in the root symplast and later, in a lesser extent, translocated to the leaves through the same channels due to their electrochemical mimicry [38]. An interesting finding was that worms showed a similar bioaccumulation pattern of $\mathrm{Zn}$ and $\mathrm{Pb}$ with respect to the mine tailing metal content. In general, it has been documented that the heavy metal accumulation pattern in mine tailings is: $\mathrm{Pb}>\mathrm{Cd}>\mathrm{Cu}$ [40-44], which corresponds to the detected metals in worms from this study, placing E. Fetida as a consistent bioindicator species which reflects the metal content from soils. Also, contrasting results about heavy metal biomagnification patterns from mine tailings to plants and from plants to animals has been reported [45, 46]. In the present study, no relationship was found between metal bioavailability in mine tailings, and heavy metal bioaccumulation in plants. In contrast, the bioavailability of $\mathrm{As}, \mathrm{Cd}$ and $\mathrm{Ni}$ in mine tailings showed an enrichment effect on the mine tailingworm relationship. This result differs from Heikens et al. [11], who reported that worms exposed to $\mathrm{Cd}$ did not show biomagnification. The relationship found in this study between the primary producer and the detritivorous ( $V$. farnesiana-E. Fetida), support the biomagnification pattern of $\mathrm{As}, \mathrm{Cu}, \mathrm{Cd}, \mathrm{Ni}, \mathrm{Pb}$ and $\mathrm{Zn}$, being $\mathrm{Pb}, \mathrm{Cd}$ and $\mathrm{As}$ the elements with higher enrichment values (1276.846, 1210.118 and 803.713 respectively). These findings are consistent with previous studies that identified $\mathrm{Pb}$ and $\mathrm{Cd}$ as the main nonessential elements transferred within a trophic chain $[41,47,48]$. In this system earthworms were the superior trophic bioreceptors with respect to the primary producers [49], which was corroborated by the biomagnification pattern of these elements.

\section{Genotoxic damage}

The results of the genotoxicity analysis in leaf tissue of $V$. farnesiana and E. fetida celomocytes showed a 
statistically significant effect of the study site (tailings vs. controls) on DNA single strand break induction, being the exposed individuals from Santa Rosa, who presented the highest levels of genotoxic damage. This is consistent with the genotoxic evaluation studies of heavy metals on primary producers and detritivorous, which have demonstrated their sensitivity to environmental metal exposure $[18,50,51]$. In general, cellular and molecular responses of toxicity in plants established in a stress environment by heavy metals are unknown. However, several studies that evaluated phytotoxic and genotoxic effects of different heavy metals on plants, reported that in most cases, and independently of the life form of the studied plant species, a significant and positive relationship exists between heavy metal concentration and the amount of mitotic abnormalities [52], number of micronuclei [53], chromosomal aberrations [54] and DNA strand breaks [55], as well as a negative and significant relationship with the mitotic index [56, 57]. This increase in DNA damage has been linked to a significant decrease in the antioxidant enzymes activity, such as superoxide dismutase (SOD), glutathione peroxidase (GPOX) and ascorbate peroxidase (APX) [55, 57].

For annelids, the exposure of both celomocytes and whole animals to heavy metals, under different conditions (ie, substrate, humidity and temperature), increases their genetic damage, which is directly related to the heavy metal concentration [58]. In this study, V. farnesiana recorded a higher genotoxic sensitivity (sensitiveness) with respect to E. fetida, presenting 13.16 times more genotoxic damage in exposed individuals than control individuals. This can be partially attributed to the cellular response of each species to heavy metal exposure, which varies considerably between taxa $[59,60]$ and also between individuals $[61,62]$. The lowest sensitivity detected in E. fetida worm with respect to the $V$. farnesiana plant, can be attributed to differences in the life history of both species (plant / animal), particularly, life cycle and number of offspring; which can determine the evolutionary response of populations to heavy metal stress, being the organisms with shorter life cycles and greater number of offspring, which have demonstrated faster adaptive responses [63, 64]. Particularly, E. fetida has been used successfully for lethal and sublethal analysis of different pollutants, concluding that long-term exposure in this species can lead to resistance responses to the evaluated pollutants $[49,65]$.

\section{Network analysis}

In addition to the analyses of metal bioaccumulation, biomagnification, and genotoxicity analyses, the application of $\mathrm{CNT}$ in this study proved to be a robust tool for the visualization of established trophic interactions between $V$. farnesiana and E. fetida. Firstly, it is observed that in both networks "site-speciesmetal concentration" and "site-species-metal concentration-genotoxic damage" the factions subgrouping of the nodes are established by species as the highest fitness. This indicates that the specificity given by each taxa is the factor that determines the metal concentration and genotoxicity levels observed, beyond the study site or type of metals detected. Previous studies have determined that the environmental characteristics such as $\mathrm{pH}$, humidity and quantity of organic matter are the main factors that facilitate the introduction of heavy metals into trophic networks [66]. The present study suggests that in this system, the species characteristics determine the detected metal concentrations. This result supports the findings documented by Hossain et al. [67], and Gall \& Rajakaruna [66] who demonstrated the ability of plants to evade heavy metal assimilation from the root, or to tolerate metal accumulation in other tissues [66, 68]. Hence, for most species, heavy metal concentrations in different tissues depend primarily on their physiology [12]. On the other hand, Mathews et al. [69] documented that the direct contact of earthworms with the contamination source, can delimit metal accumulation. Also, in a review study about the accumulation of $\mathrm{Cu}, \mathrm{Cd}, \mathrm{Pb}$ and $\mathrm{Zn}$ (from 1993 to 1998) in terrestrial invertebrates, Heikens et al. [41] mentioned that metal concentrations were highest in isopods, followed by lumbricids, and low in coleopteran, related to the edaphic habitat and food characteristics of each rate. Some showed cumulative preferences for some metals, such as worms that consistently exhibited high $\mathrm{Cd}$ bioaccumulation.

Secondly, it was identified that despite the bidirectional relationship established between both species, the nodes of $E$. fetida presented the highest values of intermediation and eigenvector centrality, as well as the lowest centrality values, identifying it as the major degree actor of linkage in the network and of greater influence. This reflects the strong impact of this species on the structure of both evaluated networks, as the main facilitators of metal flow and propagation, even above the primary producers. Actually, there are no studies with a complex system approach in trophic networks exposed to pollutants, which can serve to compare with the present study. Nevertheless, the analysis of the centrality measures obtained agrees with the vision of Jouquet et al. about earthworms as the ecosystemic engineers [29, $36]$, since they modulate the availability of resources and conditions for other species, both directly and 
indirectly [70-72]. Moreover, this group is considered among the most important edaphic engineers, due to its ability to construct mineralorganic structures with specific chemical, physical and biological functions, while moving through the soil [73-75]. However, the bidirectional relationship between species reflects that the soil engineering depends on the feedback between the organisms that control and modify the environment, and the selective environments that other species provide [76], in this case $V$. farnesiana.

\section{Conclusion}

Our results show that there is en effect of the study site on heavy metal bioaccumulation and DNA damage induction, and that these responses are particular to each species and to each bioaccumulated metal, which in turn reveals specific sensitivity for each trophic level. Moreover, the application of CNT methodology allowed us to clarify in this particular system, the interaction types and the principal components of the trophic web. Also, we showed that despite the bidirectional trophic relationship established between E. fetida and V. farnesiana, E. fetida presents the major degree of linkage in the evaluated networks, as the actor with the greater influence. Our study also confirms the importance of the application of CNT as a holistic tool for the visualization of established trophic interactions in polluted areas, as a possible indicator of the ecosystem health.

\section{Appendix 1}

Table 2 Centrality measures of the nodes corresponding to the network established by the relationship between sites (tailing 1, tailing 2), species (Vachellia farnesiana, Eisenia fetida), and heavy metals (mg / kg)

\begin{tabular}{llll}
\hline Node ID & Betweenness & Eigenvector centrality & Closeness \\
\hline E. fetida tailing1 & 479.000 & 0.444 & 123 \\
E. fetida tailing2 & 433.000 & 0.421 & 125 \\
V. farnesiana tailing1 & 278.583 & 0.305 & 132 \\
V. farnesiana tailing2 & 214.000 & 0.258 & 135 \\
Mn $(<50)$ & 12.239 & 0.195 & 138 \\
Ni $(<30)$ & 12.239 & 0.195 & 138 \\
$\mathrm{~Pb}(<100)$ & 12.239 & 0.195 & 138 \\
Al $(1000-5000)$ & 7.111 & 0.159 & 140 \\
Cu $(10-40)$ & 7.000 & 0.159 & 140 \\
$\mathrm{Ni}(30-60)$ & 4.462 & 0.137 & 145 \\
As $(<50)$ & 3.111 & 0.118 & 152 \\
Cd $(<100)$ & 3.000 & 0.118 & 152 \\
Cd $(>200)$ & 3.000 & 0.118 & 152 \\
Co $(3-9)$ & 3.000 & 0.118 & 152
\end{tabular}

Table 2 Centrality measures of the nodes corresponding to the network established by the relationship between sites (tailing 1, tailing 2), species (Vachellia farnesiana, Eisenia fetida), and heavy metals (mg / kg) (Continued)

\begin{tabular}{|c|c|c|c|}
\hline Node ID & Betweenness & Eigenvector centrality & Closeness \\
\hline Co $(<3)$ & 3.000 & 0.118 & 152 \\
\hline $\mathrm{Fe}(500-5000)$ & 3.000 & 0.118 & 152 \\
\hline $\mathrm{Fe}(>5000)$ & 3.000 & 0.118 & 152 \\
\hline $\operatorname{Mn}(>100)$ & 3.111 & 0.118 & 152 \\
\hline Mo (1-3) & 3.111 & 0.118 & 152 \\
\hline $\mathrm{Pb}(100-300)$ & 3.111 & 0.118 & 152 \\
\hline $\mathrm{Pb}(>300)$ & 3.111 & 0.118 & 152 \\
\hline$V(<5)$ & 3.111 & 0.118 & 152 \\
\hline Zn (100-500) & 3.111 & 0.118 & 152 \\
\hline $\mathrm{Al}(<1000)$ & 0.462 & 0.077 & 166 \\
\hline $\mathrm{Ba}(20-30)$ & 0.462 & 0.077 & 166 \\
\hline $\mathrm{Ba}(<20)$ & 0.462 & 0.077 & 166 \\
\hline $\mathrm{Ca}(<1500)$ & 0.462 & 0.077 & 166 \\
\hline $\mathrm{Cu}(<10)$ & 0.000 & 0.077 & 166 \\
\hline $\mathrm{Fe}(<500)$ & 0.000 & 0.077 & 166 \\
\hline Mg (1500-2000) & 0.000 & 0.077 & 166 \\
\hline $\mathrm{Mg}(>2000)$ & 0.000 & 0.077 & 166 \\
\hline $\operatorname{Zn}(<100)$ & 0.462 & 0.077 & 166 \\
\hline As $(>100)$ & 0.000 & 0.061 & 169 \\
\hline $\mathrm{Cd}(100-200)$ & 0.000 & 0.061 & 169 \\
\hline Co $(>9)$ & 0.000 & 0.061 & 169 \\
\hline Mn (50-100) & 0.000 & 0.061 & 169 \\
\hline Mo $(>3)$ & 0.000 & 0.061 & 169 \\
\hline $\mathrm{Ni}(>60)$ & 0.000 & 0.061 & 169 \\
\hline$V(5-15)$ & 0.000 & 0.061 & 169 \\
\hline $\mathrm{Al}(>5000)$ & 0.000 & 0.057 & 171 \\
\hline As (50-100) & 0.000 & 0.057 & 171 \\
\hline $\mathrm{Cu}(>40)$ & 0.000 & 0.057 & 171 \\
\hline Mo $(<1)$ & 0.000 & 0.057 & 171 \\
\hline$V(>15)$ & 0.000 & 0.057 & 171 \\
\hline $\mathrm{Zn}(>500)$ & 0.000 & 0.057 & 171 \\
\hline $\mathrm{Ba}(>30)$ & 0.000 & 0.042 & 178 \\
\hline $\mathrm{Mg}(<1500)$ & 0.000 & 0.042 & 178 \\
\hline $\mathrm{Ca}(>1500)$ & 0.000 & 0.035 & 181 \\
\hline
\end{tabular}




\section{Appendix 2}

Table $\mathbf{3}$ Centrality measures of the nodes corresponding to the network established by the relationship between sites (tailing 1, tailing 2), species (Vachellia farnesiana, Eisenia fetida), heavy metals (mg / kg), and DNA damage [ $\mu \mathrm{m}]$

\begin{tabular}{|c|c|c|c|}
\hline Node ID & Betweenness & $\begin{array}{l}\text { Eigenvector } \\
\text { centrality }\end{array}$ & Closeness \\
\hline E. fetida tailing1 & 515.583 & 0.437 & 132 \\
\hline E. fetida tailing2 & 483.083 & 0.413 & 133 \\
\hline V. farnesiana tailing2 & 353.583 & 0.307 & 139 \\
\hline V. farnesiana tailing1 & 249.750 & 0.278 & 143 \\
\hline $\operatorname{Mn}(<50)$ & 12.352 & 0.190 & 147 \\
\hline $\mathrm{Ni}(<30)$ & 12.352 & 0.190 & 147 \\
\hline $\mathrm{Pb}(<100)$ & 12.352 & 0.190 & 147 \\
\hline $\mathrm{Al}(1000-5000)$ & 8.281 & 0.153 & 149 \\
\hline Cu (10-40) & 8.281 & 0.153 & 149 \\
\hline High genotoxicity [41-95] & 6.447 & 0.149 & 151 \\
\hline $\mathrm{Ni}(30-60)$ & 5.905 & 0.135 & 154 \\
\hline As $(<50)$ & 2.947 & 0.112 & 163 \\
\hline $\mathrm{Cd}(<100)$ & 2.947 & 0.112 & 163 \\
\hline $\mathrm{Cd}(>200)$ & 2.947 & 0.112 & 163 \\
\hline Co $(3-9)$ & 2.947 & 0.112 & 163 \\
\hline $\operatorname{Co}(<3)$ & 2.947 & 0.112 & 163 \\
\hline Fe $(500-5000)$ & 2.947 & 0.112 & 163 \\
\hline $\mathrm{Fe}(>5000)$ & 2.947 & 0.112 & 163 \\
\hline$M n(>100)$ & 2.947 & 0.112 & 163 \\
\hline Mo (1-3) & 2.947 & 0.112 & 163 \\
\hline $\mathrm{Pb}(100-300)$ & 2.947 & 0.112 & 163 \\
\hline $\mathrm{Pb}(>300)$ & 2.947 & 0.112 & 163 \\
\hline$V(<5)$ & 2.947 & 0.112 & 163 \\
\hline $\mathrm{Zn}(100-500)$ & 2.947 & 0.112 & 163 \\
\hline $\mathrm{Al}(<1000)$ & 0.571 & 0.077 & 175 \\
\hline $\mathrm{Ba}(20-30)$ & 0.571 & 0.077 & 175 \\
\hline $\mathrm{Ba}(<20)$ & 0.571 & 0.077 & 175 \\
\hline $\mathrm{Ca}(<1500)$ & 0.571 & 0.077 & 175 \\
\hline $\mathrm{Cu}(<10)$ & 0.571 & 0.077 & 175 \\
\hline $\begin{array}{l}\text { Medium genotoxicity } \\
{[10-40]}\end{array}$ & 0.571 & 0.077 & 175 \\
\hline $\mathrm{Fe}(<500)$ & 0.571 & 0.077 & 175 \\
\hline Mg (1500-2000) & 0.571 & 0.077 & 175 \\
\hline$M g(>2000)$ & 0.571 & 0.077 & 175 \\
\hline $\mathrm{Zn}(<100)$ & 0.571 & 0.077 & 175 \\
\hline $\mathrm{Al}(>5000)$ & 0.000 & 0.055 & 182 \\
\hline As (50-100) & 0.000 & 0.055 & 182 \\
\hline As $(>100)$ & 0.000 & 0.058 & 181 \\
\hline $\mathrm{Ba}(>30)$ & 0.000 & 0.041 & 188 \\
\hline $\mathrm{Ca}(>1500)$ & 0.000 & 0.037 & 192 \\
\hline
\end{tabular}

Table 3 Centrality measures of the nodes corresponding to the network established by the relationship between sites (tailing 1, tailing 2), species (Vachellia farnesiana, Eisenia fetida), heavy metals (mg / kg), and DNA damage [um] (Continued)

\begin{tabular}{llll}
\hline Node ID & Betweenness & $\begin{array}{l}\text { Eigenvector } \\
\text { centrality }\end{array}$ & Closeness \\
\hline Cd (100-200) & 0.000 & 0.058 & 181 \\
Co $(>9)$ & 0.000 & 0.058 & 181 \\
Cu $(>40)$ & 0.000 & 0.055 & 182 \\
Low genotoxicity $[<10]$ & 0.000 & 0.041 & 188 \\
Mg $(<1500)$ & 0.000 & 0.041 & 188 \\
Mn (50-100) & 0.000 & 0.058 & 181 \\
Mo $(<1)$ & 0.000 & 0.055 & 182 \\
Mo $(>3)$ & 0.000 & 0.058 & 181 \\
Ni $(>60)$ & 0.000 & 0.058 & 181 \\
V (5-15) & 0.000 & 0.058 & 181 \\
V (>15) & 0.000 & 0.055 & 182 \\
Zn $(>500)$ & 0.000 & 0.055 & 182 \\
\hline
\end{tabular}

\section{Abbreviation \\ CNT: Complex network theory}

\section{Acknowledgments}

We thank the "Doctorado en Ciencias Naturales" and the "Maestría en Biología Integrativa en Biodiversidad y Conservación", both programs within the Autonomous University of Morelos State (UAEM), for the facilities granted to carry out this project. Also to Dr. N. Vázquez-Benítez for the English language editing.

\section{Funding}

Financial support was provided by Consejo Nacional de Ciencia y Tecnología (CONACyT) through the assignment of the doctoral scholarship to LTCR (405123) and postdoctoral to MRL (323084).

\section{Availability of data and materials}

Please contact author for data request.

\section{Authors' contributions}

Conceived and designed the experiments: LTCR, ETS. Performed the experiments: LTCR. Analyzed the data: LTCR, MRL, ETS. Contributed reagents/ materials/analysis tools: PMG, MLOH, ESS. Wrote the paper: LTCR, MRL, ETS, PMG. Critically evaluated the manuscript: MRLP, PMG, ETS. All authors read and approved the final manuscript.

\section{Ethics approval}

Not applicable.

\section{Competing interests}

The authors declare that they have no competing interests.

\section{Publisher's Note}

Springer Nature remains neutral with regard to jurisdictional claims in published maps and institutional affiliations.

\section{Author details}

'Doctorado en Ciencias Naturales, Facultad de Ciencias Biológicas, Universidad Autónoma del Estado de Morelos (UAEM), Universidad 1001, C.P. 62209 Chamilpa, Morelos, Mexico. ${ }^{2}$ Maestría en Biología Integrativa en Biodiversidad y Conservación, Centro de Investigación en Biodiversidad y Conservación (CIByC), UAEM, Universidad 1001, C.P. 62209 Chamilpa, 
Morelos, Mexico. ${ }^{3}$ Laboratorio de Investigaciones Ambientales, Centro de Investigación en Biotecnología (CEIB), UAEM, Universidad 1001, C.P. 62209 Chamilpa, Morelos, Mexico. ${ }^{4}$ Laboratorio de Marcadores Moleculares, CIByC, UAEM, Universidad 1001, C.P. 62209 Chamilpa, Morelos, Mexico.

\section{Received: 27 November 2017 Accepted: 8 May 2018 Published online: 18 May 2018}

\section{References}

1. Saint-Béat B, Baird D, Asmus H, Asmus R, Bacher C, Pacella SR, Niquil N. Trophic networks: how do theories link ecosystem structure and functioning to stability properties? A review. Ecol Indic. 2015;52:458-71.

2. Fath BD, Scharler UM, Ulanowicz RE, Hannon B. Ecological network analysis: network construction. Ecol Model. 2007;208:49-55.

3. Watts DJ, Strogatz SH. Collective dynamics of 'small world' networks. Nature. 1998;393:440-2.

4. Dorogovtsev SN, Mendes JFF. Evolution of networks: from biological nets to the internet and WWW. Oxford: Oxford University Press; 2003.

5. Newman MEJ. Networks: an introduction. Oxford: Oxford University Press; 2010.

6. Wasserman S, Faust K. Social network analysis: methods and applications. Cambridge: Cambridge University Press; 1994.

7. Gao W, Li Q, Zhao B, Cao G. Multicasting in delay tolerant networks: a social network perspective. Proc ACM Mobi Hoc. 2009;1:299-308.

8. Xu B, Sun F, Yang C, Gao D, Ren J. Adaptive discrete-time controller design with neural network for hypersonic flight vehicle via back-stepping. Int J Control. 2011;84:1543-52.

9. Costa LDF, Rodrigues FA, Cristino AS. Complex networks: the key to systems biology. Genet Mol Biol. 2008;31:591-601.

10. Christian RR, Baird D, Luczkovich J, Johnson JC, Scharler UM, Ulanowicz RE. Role of network analysis in comparative ecosystem ecology of estuaries. In: Belgrano A, Scharler UM, Dunne J, Ulanowicz RE, editors. Aquatic food webs. Oxford: Oxford University Press; 2005. p. 25-40.

11. Heymans JJ, Coll M, Libralato S, Morissette L, Christensen V. Global patterns in ecological indicators of marine food webs: a modelling approach. PLoS One. 2014;9:e95845.

12. Gall JE, Boyd RS, Rajakaruna N. Transfer of heavy metals through terrestrial food webs: a review. Environ Monit Assess. 2015;187:201.

13. Tovar-Sánchez E, Cervantes LT, Martínez C, Rojas E, Valverde M, OrtizHernández ML, Mussali-Galante P. Comparison of two wild rodent species as sentinels of environmental contamination by mine tailings. Environ Sci Pollut Res. 2012;19:1677-86.

14. Zhu D, Ke X, Wu L, Christie P, Luo Y. Biological transfer of dietary cadmium in relation to nitrogen transfer and $15 \mathrm{~N}$ fractionation in a soil collembolanpredatory mite food chain. Soil Biol Biochem. 2016;101:207-16.

15. Braune B, Muir D, DeMarch B, Gamberg M, Poole K, Currie R, Dodd M, Duschenko W, Eamer J, Elkin B, Evans M, Grundy S, Hebert C, Johnstone R, Kidd K, Koenig B, Lockhart L, Marshall H, Reimer K, Sanderson J, Shutt L. Spatial and temporal trends of contaminants in Canadian Arctic freshwater and terrestrial ecosystems: a review. Sci Total Environ. 1999;230:145-207.

16. Mussali-Galante P, Tovar-Sánchez E, Valverde V, Valencia-Cuevas L, Rojas E. Evidence of population genetic effects in Peromyscus melanophrys chronically exposed to mine tailings in Morelos, Mexico. Environ Sci Pollut Res. 2013;20:7666-79.

17. Prosi F. Heavy metals in aquatic organisms. In: Förstner U, Wittmann G, editors. Metal pollution in the aquatic environment. New York: Springer; 1981. p. 271-323.

18. Fourie F, Reinecke SA, Reinecke AJ. The determination of earthworm species sensitivity differences to cadmium genotoxicity using the comet assay. Ecotoxicol Environ Saf. 2007;67:361-8.

19. Li CC, Dang F, Cang L, Zhou DM, Peijnenburg WJGM. Internal distribution of cd in lettuce and resulting effects on cd trophic transfer to the snail: Achatina fulica. Chemosphere. 2015;135:123-8.

20. Pey B, Nahmani J, Auclerc A, Capowiez Y, Cluzeau D, Cortet J, Decaëns T, Deharveng L, Dubs F, Joimel S. Current use of and future needs for soil invertebrate functional traits in community ecology. Basic Appl Ecol. 2014; 15:194-206.

21. Gómez-Bernal J, Santana-Carillo J, Romero-Martin F, Armienta-Hernández M, Morton-Bermea O, Ruíz-Huerta E. Plantas de sitios contaminados con desechos mineros en Taxco, Guerrero, Mexico. Bol Soc Bot México. 2010;87: $131-3$.
22. Olea C, Zúñiga K. Plantas con potencial Para fitorremediación de suelos contaminados con metales pesados en El Fraile, Guerrero. Guerrero: Universidad Autónoma de Guerrero; 2009.

23. Galarza Z. Especiación química de elementos potencialmente tóxicos en los Jales "El Fraile" en Santa Rosa, municipio de Taxco, Guerrero. Guerrero: Universidad Autónoma de Guerrero; 2009.

24. Ruíz E, Armienta M. Acumulación de arsénico y metales pesados en maíz en suelos cercanos a Jales o residuos mineros. Rev Int Contam Ambie. 2012;28: 103-17.

25. Talavera O, Yta M, Moreno R, Dótor A, Flores N, Durante C. Mineralogy and geochemistry of sulfide-bearing tailings from silver mines in the Taxco, Mexico area to evaluate their potential environmental impact. Geofis Int. 2005:44:49-64.

26. Tice R, Agurell E, Anderson D, Burlinson B, Hartmann A, Kobayashi H, Miyamae Y, Rojas E, Ryu J, Sasaki Y. Single cell gel/comet assay: guidelines for in vitro and in vivo genetic toxicology testing. Environ Mol Mutagen. 2000;35:206-21.

27. Zar JH. Biostatistical analysis. New Jersey: Prentice-Hall; 2010.

28. Bavelas A. A mathematical model for group structures. Hum Organ. 1948;7: 16-30.

29. Barabási AL. Linked: the new science of networks. Massachusetts: Perseus; 2003.

30. Freeman LC. A set of measures of centrality based upon betweenness. Sociometry. 1977;40:35-41.

31. Freeman LC. Centrality in networks: I. Conceptual clarification. Soc Networks. 1979;1:215-39.

32. Bonacich P. Power and centrality: a family of measures. Am J Sociol. 1987; 92:1170-82.

33. Borgatti SP. Netdraw network visualization. Massachusetts: Analytic Technologies; 2002.

34. Newman MEJ, Barasabi Al, Watts DJ. The structure and dynamics of complex networks. Princeton: Princeton University Press; 2004.

35. Adriano D. Trace elements in terrestrial environments. Biogeochemistry, bioavailability and risk of metals. New York: Springer-Verlag; 2001.

36. Barceló J, Llugany M, Lombini A, Poschenrieder C. Glycine may contribuye to the protection of Silene armeria against excess copper. In: Li CJ, editor. Plant nutrition for food security, human health and environmental protection. Pekín: Tsinghua University Press; 2005. p. 634-5.

37. Prasad MNV. Heavy metal stress in plants: from biomolecules to ecosystems. 2nd ed. New Delhi: Narosa Publishing House; 2004.

38. Robinson BH, Bañuelos G, Conesa HM, Evangelou MW, Schulin R. The phytomanagement of trace elements in soil. Crit Rev Plant Sci. 2009;28: 240-66.

39. Guerinot ML. The ZIP family of metal transporters (review). Biochim Biophys Acta. 2000;1465:190-8.

40. Beyer WN, Patter OH, Sileo L, Hoffman DJ, Mulhern BM. Metal contamination in wildlife living near two zinc smelters. Environ Pollut. 1985; 38:63-86.

41. Heikens A, Peijnenburg WJGM, Henricks AJ. Bioaccumulation of heavy metals in terrestrial invertebrates. Environ Pollut. 2001;113:385-93.

42. Lukán M. Heavy metals in alpine terrestrial invertebrates. Oecologia. 2009;18:31-8.

43. Morgan JE, Morgan AJ. Calcium-lead interactions involving earthworms. I: the effect of exogenous calcium on lead accumulation by earthworms under field and laboratory conditions. Environ Pollut. 1988;12:235-47.

44. Van Gestel CA, Koolhaas JE, Hamers T, Van Hoppe M, Van Roovert M, Korsman C, Reinecke SA. Effects of metal pollution on earthworm communities in a contaminated floodplain area: linking biomarker, community and functional responses. Environ Pollut. 2009;157:895-903.

45. Goodyear KL, McNeill S. Bioaccumulation of heavy metals by aquatic macroinvertebrates of different feeding guilds: a review. Sci Total Environ. 1999; 229:1-19.

46. Leita L, Enne G, Nobili DM, Baldini M, Sequi P. Heavy metal bioaccumulation in lamb and sheep bred in smelting and mining areas of S.W. Sardinia (Italy). Bull Environ Contam Toxicol. 1991;46:887-93.

47. Van Gestel CA, Dirven-Van Breemen EM, Baerselman R. Accumulation and elimination of cadmium, chromium, and zinc and effects of grown and reproduction in Eisenia andrei (Oligochaeta, Annelida). Sci Total Environ. 1993:(Suppl 1):585-97.

48. Zhuang P, Huiling ZOU, Wensheng SHU. Biotransfer of heavy metals along a soil-plant-insect-chicken food chain: field study. J Environ Sci. 2009;21:849-53. 
49. Cortet J, Gomot-De Vauflery A, Poinsot-Balaguer N, Gomot L, Texier C, Cluzeau D. The use of invertebrate soil fauna in monitoring pollutant effects. Eur J Soil Biol. 1999;35:115-34.

50. Caetano-Pereira CM, Pagliarini MS, Brasil EM, Martins. Influence of aluminium in causing chromosome stickiness in maize microsporocytes. Maydica. 1995:40:325-30.

51. Xiao NW, Song Y, Ge F, Liu XH, Ou-Yang ZY. Biomarkers responses of the earthworm Eisenia fetida to acetochlor exposure in OECD soil. Chemosphere. 2006:65:907-12.

52. Aksoy O, Erbulucu T, Öner S, Tekeli IB. Phytotoxic and genotoxic effects of water samples taken from the eastern channel of Kocaeli on Vicia faba and Zea mays. Fres Environ Bull. 2012;21:1819-26.

53. Erturk FA, Nardemir G, Agar G. Molecular determination of genotoxic effects of cobalt and nickel on maize (Zea mays L.) by RAPD and protein analyses. Toxicol Ind Health. 2013;29:662-71.

54. Promkaew N, Soontornchainaksaeng P, Jampatong S, Rojanavipart P. Toxicity and genotoxicity of pendimethalin in maize and onion. KJNS. 2010;44:1010-5.

55. Dukesnoy I, Champeau GM, Evray G, Ledoigt G, Piquet-Pissaloux A. Enzymatic adaptations to arsenic-induced oxidative stress in Zea mays and genotoxic effect of arsenic in root tips of Vicia faba and Zea mays. C R Biol. 2010:333:814-24.

56. Kumar-Rai $P$, Kumar $G$. The genotoxic potential of two heavy metals in inbred lines of maize (Zea mays L.). Turk J Bot. 2010;34:39-46.

57. Malekzadeh P, Khara J, Farshian S, Jamal-Abad AK, Rahmatzadeh S. Cadmium toxicity in maize seedlings: changes in antioxidant enzyme activities and root growth. Pak J Biol Sci. 2007;10:127-31.

58. Reinecke SA, Reinecke AJ. The comet assay as biomarker of heavy metal genotoxicity in earthworms. Arch Environ Contam Toxicol. 2004;46:208-15.

59. Krishnaveni M, Chandrasekar R, Amsavalli L, Madhaiyan P, Durairaj S. Air pollution tolerance index of plants at Perumalmalai Hills, Salem, Tamil Nadu, India. IJPSRR. 2013;20:234-9.

60. Rosa CEV, Sierra M, Radetski CM. Use of plant tests in the evaluation of textile effluent toxicity. Ecotoxicol Environ Res. 1999;2:56-61.

61. Rai PK. Impacts of particulate matter pollution on plants: implications for environmental biomonitoring. Ecotoxicol Enviro Saf. 2016;129:120-36.

62. Calow P. General principles and overview. In: Calow P, editor. Handbook of ecotoxicology. London: Blackwell Scientific Publications; 1993. p. 1-5.

63. Morgan AJ, Kille P, Stürzenbaum SR. Microevolution and ecotoxicology of metals in invertebrates. Environ Sci Technol. 2007;41:1085-96.

64. Posthuma L, Van Straalen NM. Heavy-metal adaptation in terrestrial invertebrates: a review of occurrence, genetics, physiology and ecological consequences. Comp Biochem Physiol Part C: Pharmacology, Toxicology and Endocrinology. 1993;106:11-38.

65. Reinecke SA, Prinsloo MW, Reinecke AJ. Resistance of Eisenia fetida (Oligochaeta) to cadmium after longterm exposure. Ecotoxicol Enviro Saf. 1999:42:75-80.

66. Gall JE, Rajakaruna N. The physiology, functional genomics, and applied ecology of heavy metal-tolerant Brassicaceae. In: Lang M, editor. Brassicaceae: characterization, functional genomics and health benefits; 2013. p. 121-48.

67. Hossain MA, Piyatida P, Teixeria da Silva JA, Fujita M. Molecular mechanism of heavy metal toxicity and tolerance in plants: central role of glutathione in detoxification of reactive oxygen species and methylglyoxal and in heavy metal chelation. J Bot. 2012; https://doi.org/ 10.1155/2012/872875.

68. Unterbrunner R, Puschenreiter $M$, Sommer $P$, Wieshammer $G$, Tlustoš $P$, Zupan M, Wenzel WW. Heavy metal accumulation in trees growing on contaminated sites in Central Europe. Environ Pollut. 2007;148:107-14.

69. Mathews S, Ma LQ, Rathinasabapathi C, Stamps RH. Arsenic reduced scaleinsect infestation on arsenic hyperaccumulator Pteris vittata L. Environ Exp Bot. 2009;65:282-6.

70. Jones CG, Lawton JH, Shachak M. Organisms as ecosystem engineers. Oikos. 1994;69:373-86.

71. Lavelle P. Functional domains in soils. Ecol Res. 2002;17:441-50.

72. Wilby A. Ecosystem engineering: a trivialized concept? TREE. 2002;17:307.

73. Brown GG, Barois I, Lavelle P. Regulation of soil organic matter dynamics and microbial activity in the drilosphere and the role of interactions with other edaphic functional domains. Eur J Soil Biol. 2000;36:177-98.

74. Jouquet P, Dauber J, Lagerlöf J, Lavelle P, Lepage M. Soil invertebrates as ecosystem engineers: intended and accidental effects on soil and feedback loops. Appl Soil Ecol. 2006;32:153-64.
75. Lavelle P. Faunal activities and soil processes: adaptive strategies that determine ecosystem function. Adv Ecol Res. 1997;27:93-132.

76. Odling-Smee FJ, Laland KN, Feldman MW. Niche construction: the neglected process in evolution. New Jersey: Princeton University Press; 2003.

\section{Ready to submit your research? Choose BMC and benefit from:}

- fast, convenient online submission

- thorough peer review by experienced researchers in your field

- rapid publication on acceptance

- support for research data, including large and complex data types

- gold Open Access which fosters wider collaboration and increased citations

- maximum visibility for your research: over $100 \mathrm{M}$ website views per year

At BMC, research is always in progress.

Learn more biomedcentral.com/submissions 